\title{
Employment relations in global production networks: Initiating transfer of practices via union involvement
}

\section{Michael Fichter}

Freie Universität, Germany

\section{Markus Helfen}

Freie Universität, Germany

\section{Jörg Sydow}

Freie Universität, Germany

\begin{abstract}
International Framework Agreements (IFAs) represent a still small but growing and particularly interesting contribution to the global regulation of employment relations. IFAs enable global union federations (GUFs) to become actively involved in co-designing employment relations within transnational corporations (TNCs) and their global production networks. Based upon theoretical insights into the challenges of transferring practices in and across organizations, we present and discuss a model of practice transfer for global production networks based on empirical data from a content analysis of IFAs and from interviews with representatives of TNCs, GUFs, and other experts. Our study contributes to an organizational theory of practice transfer. But more importantly, it aims at a better integration of IHRM and international industrial relations by looking more closely at the particular role of GUFs as external actors.
\end{abstract}

\section{Keywords}

international human resource management, international labour relations, interorganizational networks, organizational stickiness, trade unions, relational control

\section{Corresponding author:}

Jörg Sydow, Department of Management, School of Business \& Economics, Freie Universität, Berlin, Boltzmannstr. 20 , Berlin 14195, Germany.

Email: joerg.sydow@fu-berlin.de 


\section{Introduction}

Over the past two decades, Transnational Corporations (TNC) have been a major force in globalizing production. While numerous campaigns have heightened public awareness of the negative impacts of this development on working conditions, only limited attention has been paid to an equally important and ongoing process to regulate employment relations on a global scale through International Framework Agreements (IFAs). In contrast to unilateral Codes of Conduct (Waddock, 2008), IFAs are based on union recognition by TNC management at headquarter (HQ) level. By the end of 2008, 72 such agreements had been signed by the central management of a TNC and a Global Union Federation (GUF). As a joint statement of commitment, an IFA is intended to secure practices that ensure compliance with basic labour standards, in particular with the core labour standards ${ }^{1}$ established by the International Labour Organization's Declaration on Fundamental Principles and Rights at Work (ILO, 1998). For this reason, we argue that IFAs present an exemplary, but so far only partially explored, case of external actor involvement in the company-specific internal transfer of particular practices of international human resource management (IHRM), namely, practices at the intersection of employment relations and corporate social responsibility (CSR).

IFAs are intended to function as a joint policy instrument. But while publications on IFAs as a policy instrument of organized labour abound (e.g. Hammer, 2005; Müller et al., 2008; Papadakis, 2008; Schömann et al., 2008; Stevis 2010; Tørres and Gunnes, 2003; Wills, 2002), much less attention has been given to management's role and to (inter-)organizational issues in regard to this topic. In this article, we address the issue of IFAs as a case of external actor involvement in the company-specific transfer of IHRM practices. Such a fresh look will not only sharpen the organizational perspective on IFAs and TNCs, but will also contribute empirically to strengthening our understanding of employee voice in IHRM and of the links to research in industrial relations.

Most recently, the involvement of external actors has entered the debate over practice transfer owing to empirical results indicating a special role of external actors in shaping business behaviour in general, and affecting the transfer of practices in particular (Collings, 2008; Greer and Hauptmeier, 2008; Preuss et al., 2009). Nevertheless, how exactly external actors are involved in the process of practice transfer, and what their special impact on the initiation of this process is, remain largely unclear. In contrast to several other studies (e.g. Bartley, 2007; Scherer and Smid, 2000), our research investigates how instead of why transfers of more decent work practices are initiated. More specifically we ask how organized representatives of labour, not only external but also internal, influence the initiation of the transfer of HRM practices within TNCs and their global production networks. By answering this question, we reintroduce a core idea of industrial relations research, namely the role of conflicts of interest and mechanisms of their resolution, into IHRM in general and the transfer of practices within and beyond TNCs in particular. Although IFAs feature a prominent role for unions and their impact on practices at the intersection of employment relations and CSR, they also represent an interesting case for external actors who might wish to influence other corporate policies and management initiatives on a global scale.

Theoretically, we draw on the practice transfer model that Szulanski (1996, 2000) developed and applied to TNCs (Jensen and Szulanski, 2004), but that has been largely 
neglected by IHRM research. For our purpose, the main virtue of this model is that it conceptualizes the basic properties of the transfer of practices as an organizational process in which sources and recipients need to overcome organizational stickiness in order to transfer practices as a 'distinct experience' of knowledge exchange (Szulanski, 2000: 17). Although we agree with Szulanski's view that transfers must be analysed as processes, we argue in favour of a two-fold refinement of his model as his framing of such processes appears to be too narrow in the case of IFAs. First, we emphasize the role of both internal and external actors additional to management in the initiation (and the overall) process of a practice transfer. This refinement acknowledges the negotiation processes that take place between management and the additional actors involved to actually produce a decision to transfer a practice. Second, Szulanski's single enterprise model of transfer needs to be extended beyond the boundaries of a TNC to capture and reflect on the inter-organizational realities of global production networks.

After relating our approach to the debate on practice transfer in the IHRM literature, we present this refined model of practice transfer. Next, we describe our methodology and report empirical findings for four TNCs that have concluded IFAs. Supplemented by a document analysis of the content of 72 IFAs as well as interviews with managers from HRM departments of other TNCs, GUF officials, local unions, and experts, our findings reveal why the process stage of initiation needs to be analysed more thoroughly than in Szulanski's original model. This is because involving an external actor with different interests adds new sources of initiation stickiness to those already identified by Szulanski. In this early phase of the process, negotiations may change the conditions for later implementation and diffusion in the TNC and its global production network. Thus, the actor constellation in the formation of a practice affects the responsibilities assigned initially to each party of the agreement, the organizational forms established to support and monitor the transfer, and the definition of its boundary of application. Following the analysis of the initiation phase of practice transfer, we offer a brief review of initial case handling experiences. As these first cases indicate, the actor constellation, the process, and the outcome of the initiation phase have a crucial impact on the subsequent implementation of HRM practices. We conclude with a summary of the contributions of our study to a conception of IHRM that takes the role of global union federations as external actors seriously.

\section{Transfer of practices within TNCs and beyond: An extended model}

Transfer of management practices in HQ-subsidiary relationships has become a major topic of the IHRM literature (and management research in general) (Brewster et al., 2008; Edwards et al., 2007; Tempel and Walgenbach, 2007), because it might reveal some insight about how institutionalization processes operate across organizational subsystems and whether a diversity of practices or, by contrast, an isomorphism according to one 'dominant' or 'best' practice, will prevail within a given TNC and its global production networks (Geppert et al., 2006; Pudelko and Harzing, 2007). The issues covered range from implementation of various HRM policies such as financial participation, diversity management, or union recognition and non-unionism (Brewster et al., 2008; 
Ferner et al., 2004, 2005; Tempel et al., 2006) to such broader issues as internationalization strategies and corporate control (Harzing and Sorge, 2003).

\section{Practice transfer in the IHRM literature}

In general, practices are recurrent actions whose reproduction is made more likely by the help of routines, rules, procedures, and similar institutions (Giddens, 1984). Within transnational management processes, practices usually originate at a central 'source' (i.e. HQ management) and are transferred to subsystems of a global production network (i.e. local subsidiaries and suppliers) located in different institutional environments. In recent years, the debate in the international management literature over the divergence/convergence dichotomy of TNCs' business models and management practices has shown that traditional expectations about TNCs' capacity and capability to manage all of their subsidiaries in a similar way are confronted by the reality of limited HQ influence (Brewster et al., 2008; Dörrenbächer and Geppert, 2006; Geppert and Williams, 2006; Harzing and Sorge, 2003). A growing body of research from different perspectives, i.e. the business systems approach, organizational neo-institutionalism, and micro-politics has shown why convergence toward one model of business conduct, comprised of one distinct set of practices in various management functions, is unlikely to be observed empirically (Bouquet and Birkinshaw, 2008; Dörrenbächer and Geppert, 2006; Edwards and Rees, 2006; Edwards et al., 1999; Geppert and Williams, 2006; Kostova et al., 2008; McSweeney et al., 2008; see Geppert et al., 2006, for a summary).

Although we acknowledge the fundamental contributions of this research in general and the extensive case study research on employment relations and IHRM conducted by Almond, Ferner, Edwards, Temple and others (e.g. Ferner et al., 2004, 2005; Ferner and Almond, 2006) in particular - to understanding implementation induced divergences in practices across countries, the focus of our article is on an aspect of the transfer of practice that this research has insufficiently addressed. Our aim is to show how the involvement of multiple actors initiates a process that may lead to the transfer of practices and the implementation of labour standards. As has been argued more generally elsewhere (Geppert et al., 2006; Hassel, 2008; Levy, 2008), TNCs are increasingly involved in global regulation and institution-building, processes in which management most definitely must deal with additional actors. With IFAs, which we regard to be a potentially significant element in the globalization of labour standards, such actors may be (internal) employee representatives (Preuss et al., 2009) or (external) trade unions.

\section{Practice transfer according to Szulanski's model}

The conclusion of an IFA is a case of external actor influence at the HQ level. For analytical purposes, we use the process-oriented approach of Szulanski $(1996,2000)$ as a starting point as this, more than most studies in IHRM, focuses on the procedural and systemic properties of the transfer process. However, we are aware of the fact that owing to the focus of this approach (at least in its earlier versions) on the intra-organizational aspects of the transfer process, influences of institutional distances were neglected to a certain extent (for an incorporation of institutional distances in the argument, see Jensen 
and Szulanski, 2004). For example, national differences in labour law, cultural diversity in cognitive attitudes, and locally idiosyncratic political struggles all play a role in the formation and transfer of labour-related management practices that are not accounted for in the original model (for attempts to make these aspects an explicit starting point for analysis see Geppert and Williams, 2006; Kostova et al., 2008; McSweeney et al., 2008). Nevertheless, we stick to this approach as it allows us to explore in more detail at which points in the process the (political) influence of external actors might play a role in initiating the transfer of practices.

According to Szulanski (2000), the transfer of any practice, including the kind involving external actors, occurs between a source and a recipient and is only completed when the recipient is able to at least partially replicate, reconstruct, and integrate a practice according to a certain template, benchmark or standard. To underline the process character of practice transfer, Szulanski's model consists of four phases: initiation, implementation, ramp-up, and integration. The phase of initiation - which is the focus of this article - starts with uncovering possible gaps, continues with finding and defining a practice to be transferred as a solution, and ends with the actual decision to transfer this practice. The initiation phase sets the stage for the subsequent phases and, as such, its connection to them is vital for local adoption, adaptation, and consecutive reproduction.

Usually the transfer process is exposed to several institutional and organizational barriers in each phase of the transfer that Szulanski summarizes under the rubric of 'organizational stickiness' (Szulanski, 2000: 12). On a general level, stickiness emerges from several sources, both systemic and actor-related, which reduce the ability of a source to transfer and impede the capability of a recipient to replicate a given practice. These sources include inherent features of the practice itself, but also agents' motivations and interests, the quality of the transfer relationship, and the organizational context.

\section{Practice transfer in an extended Szulanski model}

In our extension of Szulanski's model, we specify additional factors of stickiness resulting from the contested nature of the transfer of labour-related practices (Table 1). The first point of extension is based on considering the constellation of actors with respect to IHRM policies of TNCs. Szulanski's model infers a kind of one-on-one relationship between HQs (source) and subsidiary (recipient), with each being presented as a different part of an otherwise homogeneous entity, i.e. management. As a consequence, he concentrates on those forms of stickiness with which management is confronted in identifying gaps and defining possible solutions. In our extension, the initiation stage of the transfer process involves additional actors, in the case of IFAs, both external and internal ones. Our special focus is on GUFs as an external actor, because without the signature of a GUF representative, there would be no IFA. As documented in their programmatic statements, GUFs have identified TNC labour relations as an important strategic leverage point to (re-) gain influence on the global organization of production by negotiating a cross-border IFA of recognized norms, principles and procedures that is supplemental to national level bargaining and legal provisions (Hammer, 2005; Müller et al., 2008; Papadakis, 2008). GUFs see IFAs as a means for securing their own recognition, creating space for organizing at the local level, and extending recognition of the core labour 
standards of the ILO (Brandl, 2006; Croucher and Cotton, 2009; Stevis, 2010). As such, there is the clear ambition of the GUFs to influence HRM practices of TNCs throughout global production networks. As a result, the initiation stage of the transfer of practices definitely becomes more complex than in a unilaterally devised management policy.

As a second and related point of extension we include global production networks as the relevant, and in several respects more 'heterarchical' (Hedlund, 1986), background structure for the whole process of IFA negotiations by recognizing the existence of local actors, their possible input, and their relationship to HQs. As TNCs bridge spatial, institutional, and organizational distances, they evolve into globally dispersed production networks, with complex supply chains and different, sometimes even plural, forms of formal governance: hierarchy, market, and hybrid (Bair, 2008; Garcia-Pont et al., 2009; Gereffi et al., 2005; Lane, 2008). However, Szulanski's model does not capture these networked configurations despite their apparent relevance for the globalization of production in general, and, especially in regard to our topic, for setting labour standards and establishing union recognition. Within the boundaries of a global production network, it may be argued that 'obligational contractual relations' (Sako, 1992) or 'relational contracting' (Macneil, 1978), at least if compared with arm's-length market relations, may be better at facilitating the improvement of employment conditions and relations (Fichter and Sydow, 2002; Frenkel, 2001; Frenkel and Kim, 2004; Xue, 2008). But one can also postulate a declining degree in labour standards' coverage with increasing distance from the core of a TNC's operation (Palpacuer, 2008; Xue, 2008). In this sense, GUFs aim to influence HQ management to take responsibility for the working conditions at the periphery of global production networks as well. As a consequence of the particular role GUFs aim to play and suppliers actually do play, the intra-organizational sources of stickiness need to be complemented by extending the model to include interorganizational ones.

Table 1 summarizes our extensions to the model of practice transfer in global production networks in regard to the role of additional actors. In the first sub-stage, it is the GUFs that push the identification of gaps in labour standards in the periphery of global production networks. In the second sub-stage it is again the GUFs as external actors that - on their own or via intermediate channels of influence like co-determination or home country union representation - may force management into negotiations over global labour practices, thereby altering the sequence of the initiation phase compared with a situation of managerial unilateralism. From these two extensions - and their relatedness to the variety of inter-organizational relations in global production networks - there follows a negotiation process of joint decision-making to formally define a solution that actors on both sides, labour and management, can agree on for transfer. In all three substages GUFs and their representatives are involved with all their organizational and individual 'knowledgeability' (Giddens, 1984)

In essence, we maintain that the way the initiation process unfolds has a strong impact on its success. We define a successful initiation of IFA related practice transfer as the establishment of a viable conflict resolution mechanism. This is a necessary precondition for an enduring and successful implementation of better working practices at the local level. A conflict resolution mechanism is viable if it enables alleged violations to be fed 
Table I Initiation of practice transfer in global production networks

\begin{tabular}{lll}
\hline Initiation phase: sub-stages & $\begin{array}{l}\text { Sources of stickiness } \\
\text { (Szulanski) }\end{array}$ & $\begin{array}{l}\text { Sources of stickiness (extended } \\
\text { model) }\end{array}$ \\
\hline Identifying a gap & $\begin{array}{l}\text { Taken-for-granted beliefs } \\
\text { and entrenched habits } \\
\text { Problem-oriented search, } \\
\text { ambiguous relationships } \\
\text { between means and ends } \\
\text { Unilateral decision, } \\
\text { (Dis-)Trust in reliability } \\
\text { and motivation of source } \\
\text { and recipient }\end{array}$ & $\begin{array}{l}\text { Identification of gap by external } \\
\text { actor initiative }\end{array}$ \\
$\begin{array}{ll}\text { Negotiation with external and } \\
\text { internal actors }\end{array}$ \\
Decision to transfer & $\begin{array}{l}\text { Joint decision-making with } \\
\text { external actor }\end{array}$ \\
& & \\
& &
\end{tabular}

back into negotiation processes at the HQ level, if its procedural conditions allow for the resolution of such cases, and if the procedure is open to possible (re-)negotiation and modification in light of implementation practice at the local level. Our assessment of the actor-related and systemic contributing factors in the sub-stages provides a sufficient basis for judging the viability of the agreed conflict resolution mechanisms.

\section{Research setting and methodology}

Our analysis of the initiation stage draws on both primary and secondary sources, which we have used, first of all, as a basis for understanding and evaluating the IFA process across our whole sample of 72 TNCs. In a second step, we have directed our analysis of these sources in particular to the four case studies presented below, which illustrate the initiation phase of the transfer of practice and the subsequently recurrent issues around the handling of violations.

\section{Data collection and analysis}

Our primary sources include both interviews and documents. Between November 2008 and December 2009 we conducted 49 semi-structured interviews with key actors from TNCs (management, works councils) and from unions (GUFs, home country trade unions) directly involved in IFA initiation processes. Each of these interviews averaged 45 minutes. With few exceptions, the interviews were recorded and transcribed. Furthermore, we completed some two dozen background interviews of a similar length with actors in the field of international labour relations. These included representatives from civil society organizations, employer associations, and academic experts on national industrial relations systems, all of whom are indirectly engaged in IFA-related processes.

Second, we carried out a comprehensive content analysis of all 72 IFAs, in which we could identify 125 substantive and procedural IFA characteristics that we divided into four general categories, i.e. actors identified by signatures, substance distinguished by 
ILO standards and itemized topics, procedures defined by monitoring bodies and implementation measures, and scope in terms of the extension to subsidiaries and suppliers. We also reviewed value statement in the preambles. Table 2 gives examples of the kinds of quotations we used for a process-oriented analysis of the data.

To extend our understanding of the organizational and institutional environment as being conducive or detrimental to the viability of collective conflict resolution as formally specified in IFAs, we collected and reviewed elementary data both on TNCs and their operations (including reports on social responsibility) and on GUFs, as well as on the relevant institutional environment of the country of origin and the host country. Finally, the authors were able to participate in several workshops, discussions, and meetings in which union and employee representatives, and managers, either engaged in IFA related activities or reflected on their approach to IFAs.

\section{Case selection and analysis}

In addition to collection and analysis of more general data, we have conducted a comparative case study for understanding the practices of transfer and the (inter-)organizational stickiness of the process in more detail (see Table 3 for an overview). Our reconstruction of the sequence of events, however stylized and reduced for presentation, provides a process analysis unattainable by a detailed review of IFA documents alone. Furthermore, each case was submitted to 'triangulation' (Jick, 1979) based on the following sources: our interviews with the HQ management and the labour side from our four cases provide insights on the first initiative and on the negotiations; second, we have the IFA texts to analyse the formal properties of the decision to transfer; and third, we use our additional interviews from the other cases to place the four selected cases within the larger field of IFA-related activities and within the wider range of IFAs' initiation processes. Similarly, we occasionally draw on our content analysis of all 72 agreements as well as on our secondary data for comparison.

In selecting the four TNCs, our first step was to eliminate those TNCs from our sample of 72 IFAs that did not meet the following three criteria: The TNC has a signed IFA with one of four GUFs ${ }^{2}$ that together, have concluded 89 percent of all IFAs; it is based in continental Europe or Scandinavia ( $85 \%$ of all TNC with IFAs), which is indicative of a European style of HRM policies and labour relations at the HQ level; and it has production facilities or subsidiaries in Brazil, India, Turkey, and the USA. We have chosen these countries because of their relevance for the changing pattern of the global division of labour. Together with China and Russia, Brazil and India belong to a group of countries that has a growing political and economical importance in the world economy. The USA is the second largest regional economy in the world (Subacchi, 2008) and a prime focus of manufacturing investments among our sample TNCs. Apart from its above average economic growth rates, Turkey is of particular regional importance for European TNCs, owing to the process of European integration. For very different reasons, the situation of compliance with core labour standards is a difficult problem in all four countries, having to do with factors such as contentious local industrial relations, peculiarities in national labour law and the impact of the informal economy. Taken together, it is fair to say that policies that fail in these countries are not likely to succeed in other places. 
Table 2. Content analysis of interviews and IFAs' texts

\begin{tabular}{ll}
\hline Initiation stage Criteria & $\begin{array}{l}\text { Major data Examples } \\
\text { Sources }\end{array}$
\end{tabular}

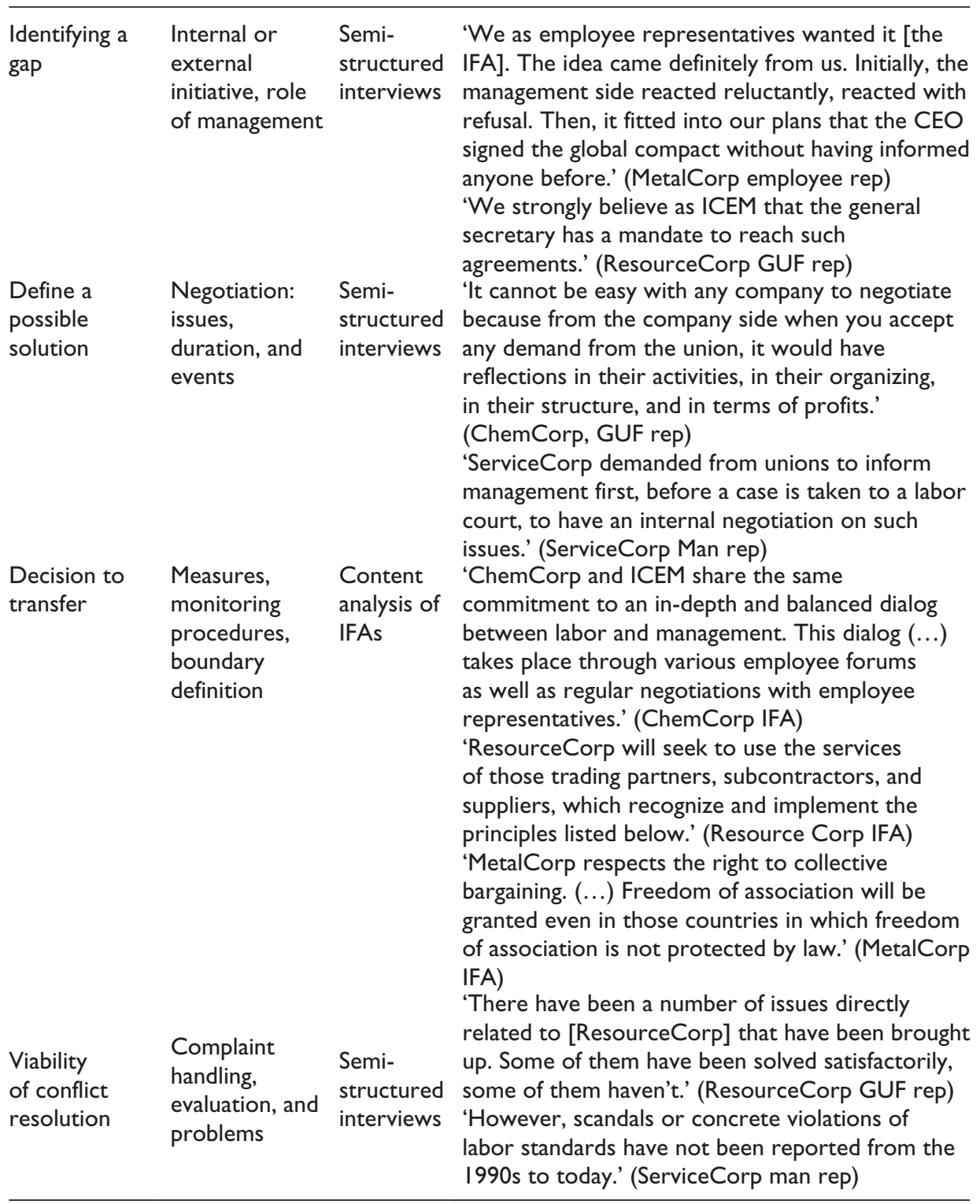

These criteria yielded a group of 12 TNCs, three per GUF. Based on information from the GUFs and from employer sources, we added one TNC to each GUF group as a control case. For these 16 TNCs we interviewed 15 managers, mostly from HRM departments or 
HRM related functions in sourcing and CSR departments. In addition, we have completed 25 interviews with the actors involved on the labour side. These include GUF officials, national union representatives or spokespersons of European/world works councils. This heterogeneity on the labour side reflects the different circumstances under which IFAs are negotiated (see below). By this approach, we completed 11 matches, i.e. 11 TNCs for which we have interviews on both sides. In a final step, we selected one case from each GUF group for a more in-depth analysis: MetalCorp (IMF), ResourceCorp (BWI/ICEM), ChemCorp (ICEM), and ServiceCorp (UNI). For each of them we have conducted two to five interviews, at least one interview for each group of respondents, i.e. management and labour.

Table 3 provides an overview of the four corporations. All of them organize their production in networks on a global scale, as do all TNC in our sample. ${ }^{3}$ However, beyond representing different sectors, the four corporations selected vary in regard to the structure of their global operations. While all four are examples of highly complex systems of subsidiaries, suppliers, joint ventures, and contractors spanning many institutionally and culturally diverse settings, they do differ in their degree of heterarchy. A 'heterarchical' TNC is characterized by subsidiaries with a significant amount of autonomy and the ability to influence HQ policies and practices (Hedlund, 1986). The most heterarchic TNC is ResourceCorp, followed by ServiceCorp, whereas MetalCorp and ChemCorp represent more centralized configuration of production networks. Moreover, each corporation represents a different size class of TNC. ServiceCorp is by far the largest, MetalCorp is also comparatively large, while ResourceCorp is very average-sized and ChemCorp is among the smallest.

Table 3. The four highlighted cases

\begin{tabular}{|c|c|c|c|c|c|c|}
\hline \multirow{2}{*}{$\begin{array}{l}\text { Company \& } \\
\text { GUF }\end{array}$} & \multirow{2}{*}{$\begin{array}{l}\text { Year } \\
\text { of IFA }\end{array}$} & \multicolumn{5}{|c|}{ Organizational context: Characteristics of the production network } \\
\hline & & Industry & $\begin{array}{l}\text { Employees } \\
2007\end{array}$ & $\begin{array}{l}\text { Home-host } \\
\text { country } \\
\text { relationships } \\
2007\end{array}$ & $\begin{array}{l}\text { Dominant } \\
\text { form of } \\
\text { subsidiary }\end{array}$ & $\begin{array}{l}\text { Type of } \\
\text { subcontracting }\end{array}$ \\
\hline $\begin{array}{l}\text { MetalCorp \& } \\
\text { IMF }\end{array}$ & 2002 & Automotive & 270,000 & 17 & $\begin{array}{l}\text { Business units } \\
\text { by product }\end{array}$ & $\begin{array}{l}\text { System } \\
\text { suppliers, } \\
\text { relational } \\
\text { subcontracting }\end{array}$ \\
\hline $\begin{array}{l}\text { ResourceCorp } \\
\& \text { BWI (ICEM) }\end{array}$ & 2005 & $\begin{array}{l}\text { Resource } \\
\text { extraction, } \\
\text { construction } \\
\text { materials }\end{array}$ & 90,000 & 77 & $\begin{array}{l}\text { Business units } \\
\text { by product }\end{array}$ & $\begin{array}{l}\text { Intensive use } \\
\text { of market } \\
\text { subcontracting }\end{array}$ \\
\hline $\begin{array}{l}\text { ChemCorp \& } \\
\text { ICEM }\end{array}$ & 2005 & $\begin{array}{l}\text { Chemicals } \\
\text { (special fibers, } \\
\text { plastics) }\end{array}$ & 15,000 & 28 & $\begin{array}{l}\text { Business units } \\
\text { by product }\end{array}$ & $\begin{array}{l}\text { relational } \\
\text { and market } \\
\text { contracting }\end{array}$ \\
\hline $\begin{array}{l}\text { ServiceCorp \& } \\
\text { UNI }\end{array}$ & 2003 & $\begin{array}{l}\text { Facility } \\
\text { services }\end{array}$ & 438,000 & 62 & $\begin{array}{l}\text { Business units } \\
\text { by region }\end{array}$ & $\begin{array}{l}\text { Minor role of } \\
\text { subcontracting }\end{array}$ \\
\hline
\end{tabular}


All four TNC are headquartered in Europe and have European works councils. Under the leadership of a corporate HQ (group management), business units are organized along product divisions or segments, except at ServiceCorp, in which legally independent business units are grouped by country/region. At ServiceCorp, subcontracting is negligible, whereas it is used extensively throughout the global operations of ResourceCorp, amounting to approximately one third of its officially reported workforce. MetalCorp is a major OEM with many suppliers (around 35,000), the most important ones have the status of system suppliers that are integrated by relational contracting. In this respect ChemCorp is somewhere in the middle between ResourceCorp and MetalCorp.

All four TNCs are confronted by different types of actors and strategies on the union side: While all of the four GUFs involved in our cases are organized along industry or sectoral lines, with affiliates in over 100 countries and aggregate memberships ranging between 12 and 25 million workers, they have distinct strategy preferences with respect to IFAs that we would characterize as follows: 'organizing' (UNI), 'countervailing power' (IMF), 'social dialogue' (ICEM), and a 'mixture' of organizing and social dialogue (BWI).

MetalCorp negotiates with the IMF, which can build on many national/local affiliated unions with high membership densities in core firms of its industry domain and, at least in many continental European firms, can make use of an influential position inside a given TNC owing to (European) works councils (Brandl, 2006). Coordinating with these two actors, the IMF is able to pursue a 'countervailing power' strategy in which national unions at HQ and works councils initiate and negotiate IFAs under the formal responsibility and leadership of the IMF (critical of this approach from a union perspective: Herrnstadt, 2007). As with MetalCorp, those TNCs with a world works council have also been among the first targets of IFA negotiations (Platzer and Müller, 2009: 120).

ResourceCorp is confronted with a more complex situation. Its major negotiation partner is the BWI that follows a mixed policy of a 'social dialogue/organizing' type depending on whether the construction or the woodworking segment of its jurisdiction is relevant (Hellmann, 2007). Since ResourceCorp's business is in construction materials, which is dependent on natural resource exploitation, in many countries its employees are represented by unions affiliated to ICEM. For this reason, ICEM joined the IFA negotiations (see below).

ChemCorp also negotiates with ICEM. Its 'social dialogue' approach is embodied in an increased focus on the pursuit of 'Global Framework Agreements' and buttressed by a considerable number of regional union networks worldwide, particularly in Latin America (Cumbers et al., 2008). Although ICEM also uses union representatives at the HQ as door-openers to management, it insists on its sole responsibility and mandate to negotiate IFAs. This is the case with ChemCorp.

Finally, ServiceCorp is confronted by UNI, which defines itself as a 'campaign union' (Union Network International, 2001: 129) and uses IFAs in the context of what we classify as an 'organizing strategy'. Operating in a domain of widespread employer disdain for unions, and lacking formalized and institutionalized channels of influence in many TNCs, UNI mobilizes its affiliates globally to exert public pressure on TNCs for negotiations over union rights and recognition. 


\section{Initiation of practice transfer within TNCs and beyond: Empirical insights}

The following presentation of our empirical evidence follows the sub-stages of the initiation phase and will emphasize the dual extensions of Szulanski's model we have proposed, i.e. the involvement of external (and internal) actors additional to management and the extension of the scope of practice transfer beyond the legal boundaries of the TNC. Our aim is to show how GUFs as external actors initiated IFAs by uncovering gaps in TNCs' adherence to labour standards, how they interacted with management in negotiations to define IFAs as a solution to closing these gaps, and how they influenced the practices to be implemented along with the monitoring mechanisms and the extent of supplier inclusion. Table 4 summarizes the results with respect to our four case studies.

\section{Taking the initiative: GUFs as external initiators}

By 'finding the gap' we are referring to a process of uncovering discrepancies between an intended practice, in this case a normative level of labour standards, and the actual practices throughout a global production network. Based on Szulanski's considerations in which taken-for-granted beliefs and entrenched habits impede the identification of a gap internally, it is probably not surprising that uncovering such a gap and designating it as a problem is done by an external actor. Exceptions, such as the ChemCorp case, are owing to the anomalous circumstance that the responsible top manager is a former trade union official, who pushes for a well-developed holistic CSR program and cooperative labour relations at HQ. In raising the issue of the existence of a gap, labour's approaches have been varied, depending on the particular constellation of actors and their strategic priorities. Whereas the internal employee representative body (works council) initiated the process at MetalCorp, the works councils at both ResourceCorp and ServiceCorp had only a passive role. Among the external actors, both the GUF and the national union were in supporting roles in the MetalCorp case. In contrast, it was the personal initiative of a leading BWI official that got the process started at ResourceCorp, and at ChemCorp, the GUF was the sole actor on the labour side. In the case of ServiceCorp, UNI took the lead in coordinating national union pressure on management to recognize the gap and enter into negotiations.

In contrast to the diversity of organizational representation on labour's side, ${ }^{4}$ management is a far more homogeneous actor. Only HQ management, first and foremost represented by managers of central HRM, ${ }^{5}$ is directly involved in negotiating IFAs. In all of our interviews with managers we recorded different degrees of resistance to labour's initiatives in this sub-stage, ranging from mere reluctance up to - at the beginning - outright refusal to bargain. Union respondents repeatedly complained about the reservation on the part of management to enter into negotiations and actively contribute to reaching an agreement. For their part, many of our management respondents were clearly interested in limiting external voice in the definition of corporate standards. They argued that their company's CSR initiatives already fulfilled the goal of transferring decent labour standards. 


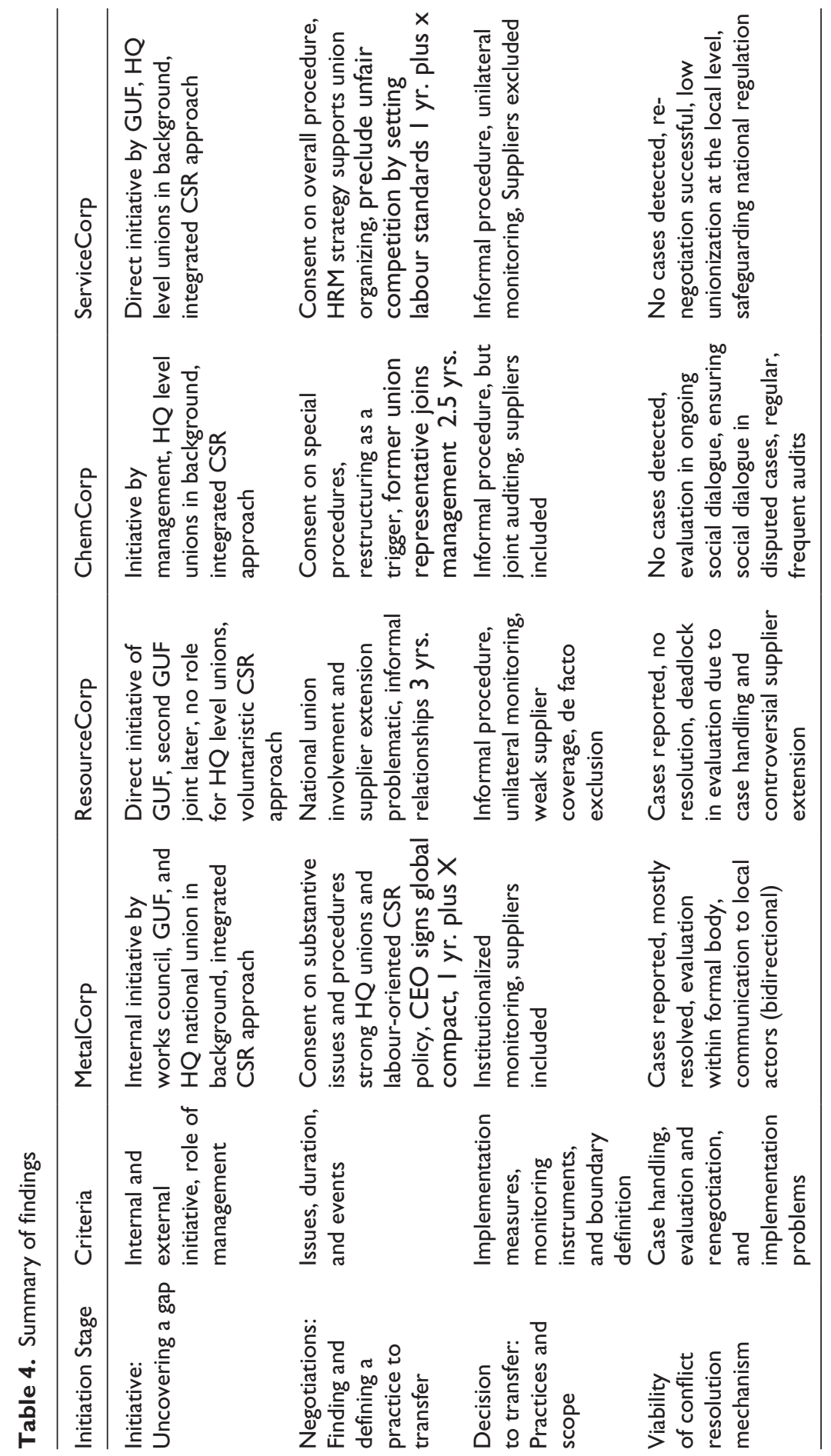


Despite such initial resistance on the management side, our selected cases show that the process can be initiated and developed. Drawing on our four cases, we find that initiation may be facilitated by a long record of cooperative industrial relations at the HQ level and an institutional environment in support of internal conflict resolution (MetalCorp, ChemCorp). In the case of ServiceCorp, management came to recognize the role of union voice and involvement as part of its corporate culture and the strategic priorities of the corporation's business model (differentiation by quality). ResourceCorp, by contrast, is more of the voluntaristic variety in which commitment to CSR, including labour-related measures, is primarily aimed at risk reduction and issue management. For this company, reputation and public relations are of priority concern.

\section{Defining the practice to be transferred:The negotiation process}

After agreement is reached about the existence of a 'gap', the second stage of the initiation phase commences. The duration of this stage differed considerably among the TNCs involved. According to our union respondents, the time between identifying the gap and the completion of the initiation phase ranged from one to four years (Table 4). Whereas negotiations at ServiceCorp and MetalCorp proceeded rather quickly, negotiations lasted for about three years in the case of ResourceCorp. However, duration may be affected by events outside of the negotiation process as in the case of ChemCorp case, where negotiations were drawn out by a major restructuring.

An important procedural factor (raised by management) is the question of labour's representation at the bargaining table. For example, the managements of both ResourceCorp and ChemCorp strictly opposed the participation of home country national unions. In contrast, at MetalCorp, the IMF had to abide by management's refusal to accept an external organization at the bargaining table. Such policy decisions by management may complicate labour's strategic goal of building the right kind of pressure for holding together the initiating actor constellation and at the same time promoting a constructive bargaining climate with management. ${ }^{6}$ These two requirements may be highly contradictory as management might balk at negotiating an IFA under external pressure.

Regarding the substance of IFAs, there are basically two issues of controversy that are characteristic of negotiations. One is the acceptance by management of union recognition clauses beyond general value-loaded statements on industrial democracy, collective bargaining, and social dialogue inserted into preambles: Almost one-half of the IFAs in our sample contain no more than explicit reference to the ILO Conventions 87 and 98 (ResourceCorp). Some 40 percent go a step further, committing management to strict neutrality during organization drives and prohibiting any interference or retaliatory measures (ChemCorp), and in 12 percent of IFAs, management support for union organizing attempts is prescribed. For example, MetalCorp commits itself to guaranteeing collective bargaining and union recognition even in countries where national regulations do not meet its home country standards. Although basically oriented toward neutrality, ServiceCorp is also exceptional on this point. In an attempt to curb unfair competition from low-cost service providers in its industry, it has agreed to contribute a substantial sum to a jointly managed union-organizing fund. 
The coverage of suppliers by the IFA is equally controversial. Extending the agreement throughout the global production network, especially to the periphery, is understandably a top priority of all GUFs. In contrast, management respondents in all four cases point to the limits of their legal responsibility by highlighting the unclear formal status of the agreement, especially in regard to international labour law and to its extension to other legal entities such as independent suppliers. As the HR manager of ResourceCorp argued, the economic rationale for foreign investment strategies of reducing labour costs and for outsourcing to business partners is questioned if standards of the TNC are extended to suppliers as well. MetalCorp too adamantly defended its prerogative to choose its business partners. But at the same time, it acknowledged responsibility for ensuring that all parts of the final product are produced under acceptable labour standards. In the case of ResourceCorp dissension on this issue impeded the progress of the initiation process, whereas in the other three cases, disagreement was overcome by a commitment on both sides to dialogue and pragmatic solutions.

\section{Decision to transfer: How to transfer and monitor the practice}

The outcome of negotiation is crucial for this third sub-stage, in which core elements of the transfer of practice, i.e. implementation, monitoring, and boundary definition, need to be specified in order to prescribe a viable mechanism of conflict resolution in the IFA. We first address the measures and instruments by which management intends to implement the results as negotiated. Second, we look at the procedures for jointly monitoring the agreement. Third, we examine the scope of the agreement within the global production network in terms of the organizational units covered.

First of all, for IFA implementation, management uses well established CSR measures such as internal reporting requirements, audits and self-checks, target agreements, compliance guidelines in manager contracts, sourcing specifications, leadership training seminars, etc. By these means, management strives to complement other processes within an already established (inter-)organizational structure used to ensure process stability in global production networks (cf. Edwards et al., 1999; Ferner et al., 2004). However, TNCs with IFAs differ considerably in regard to external actor involvement in decision-making on implementation measures. Those with an integrated CSR approach, such as ServiceCorp, consult directly with labour on a regular basis in the interest of a global strategy on labour relations. In contrast, those TNCs with a more voluntaristic approach to CSR (e.g. ResourceCorp), restrict union involvement to informal and unfocused consultation within bodies such as a sustainability stakeholder council. ChemCorp, which undertakes yearly joint fact finding missions with ICEM to subsidiaries, and MetalCorp, are representative of those TNCs with a cooperative style of labour relations, integrating, for example, labour standards into management manuals for auditing business processes and standards, or including such standards in performance measurements for local managers and factory supervisors. In addition, MetalCorp has decided to introduce a jointly organized hotline at HQ as a formal complaint procedure involving both parties in the handling of individual complaints. Interestingly, in all four cases union representatives as well as managers consider IFAs as a means for enhancing the monitoring capacities of the TNC and its global production network. 
Second, in our sample of 72 IFAs, we can distinguish two basic forms of conflict resolution in the organization of monitoring, depending on the extent of institutionalization: (1) highly institutionalized forms of monitoring IFAs that involve a specially designated body or a European or world works council, and (2) weaker forms relying on 'meetings'. With the latter, future replication of negotiations - and hence the transfer of practices rests more on goodwill and informal relationships and commitment than a formally agreed procedure. Across all IFAs, the number of TNCs without an organization-wide rule for reporting any violation of labour standards and with 'meetings' as the mode of formal monitoring is considerably high $(41.2 \%)$. Where GUFs need to use the influence of the European Works Council or the works council for opening the initiation phase, we find that monitoring gives this body formal recognition (e.g. MetalCorp). Where only GUFs have been directly involved in the process, monitoring is assigned to 'meetings', a significantly less institutionalized and ad hoc form of conflict resolution (ResourceCorp, ServiceCorp, ChemCorp).

Nevertheless, this finding needs to be interpreted in conjunction with an overall assessment of implementation and monitoring procedures as they are continually developing. For example, the ChemCorp IFA refers only to meetings for consultation on alleged violations, but as noted above, the actual practice of joint audits with the ICEM at production facilities and ICEM's involvement in the operation of a hotline are indications of a stronger institutionalization. In contrast, ServiceCorp and ResourceCorp lack a hotline and rely only on meetings for monitoring. ${ }^{7}$

Finally, in regard to the definition of the IFA's boundaries, as we reported above, the extension to suppliers throughout the global production network is highly controversial. This is reflected in our content analysis of 72 IFAs, which shows that in 44 percent of them, suppliers are either not mentioned or are referred to only in conjunction with voluntary measures such as workshops and discussions on compliance. Such voluntary forms of integrating suppliers are to be found where IFA monitoring is weakly institutionalized; in contrast, some form of sanction is much more likely in IFAs with more institutionalized forms of monitoring. We also found that the inclusion of an individual complaint procedure (often a management-promoted instrument) goes along with a stronger integration of suppliers in terms of sanctions against failure to comply with IFAs' standards.

\section{Viability of conflict resolution: Evaluation of initiation outcomes}

The focus of this article is on the initiation phase of the transfer process. Although we lack, at present, sufficient empirical evidence to address the subsequent phase of implementation (not to mention ramp-up and integration), we are well aware of the intrinsic connection between initiation and implementation and of the need for its close examination. However, we are able to add to an understanding of the initiation phase by briefly reviewing assessments from our respondents regarding the handling of the first reported cases of alleged violations and implementation problems. For HQ level actors, such case-handling in the context of monitoring procedures is a crucial element for judging the process of implementation and whether the transfer of practices has been successfully initiated in terms of necessary replication. 
Our data show that alleged violations of labour standards have been reported for many different countries, including those in our research focus: Brazil, India, Turkey, and the USA. Interestingly, the most frequent ones concern avoidance of union recognition and collective bargaining in the USA. By contrast, violation reports from Brazil have been rare and with reference to less serious infringements (undue wage cuts, unjustified dismissals, conflict between different local unions, unconfirmed cases of child labour). Similar cases are reported from Turkey, while the cases from India include very severe violations (violence against workers and their representatives, child labour). In reference to the problems of implementation, explanations for such violations include the fluidity and complexity of operations in global production networks, the number of subsidiaries, suppliers and sub-contractors, and the diversity of country-specific institutional settings. Labour representatives pointed to management failures to provide adequate manpower and financial resources for implementation, but also to their own lack of such resources. For management, such criticisms were often regarded as being exaggerated.

Among our four cases, ResourceCorp, with its weak monitoring provisions, appears to have the greatest problems of implementation, most of which concern the highly controversial issue of the extension to suppliers. Reports of violations do reach the HQ level, but management consistently rejects responsibility for legally independent entities. According to the GUFs, these are the product of out-sourcing decisions by ResourceCorp itself. We interpret the situation at ResourceCorp as an indication of the problems associated with a conflict resolution mechanism that entirely relies on informal procedures. Moreover, this case clearly shows how the differences and conflicts that were already evident in earlier sub-stages of the initiation phase turn out to be almost insurmountable in the face of violation reports at the supplier level.

By comparison, the implementation problems at ChemCorp, ServiceCorp, and MetalCorp have been reported to be much less severe. At MetalCorp, a fairly high number of cases have been reported, including some from its home country, but with the exception of one case that is still pending, all have been resolved consensually by following the formal IFA procedure. For employee representatives at MetalCorp HQ, who led the initiation process on labour's side, the greatest obstacle to implementation has been the critical stance toward IFAs adopted by US metalworking unions (Herrnstadt, 2007). Regarding the issue of boundary definition, the extension to suppliers has been re-negotiated, linking the IFA to the regular sourcing procedures and assigning the responsible sourcing manager to the team for handling reported violations on the operational level.

Despite the apparent reluctance on the part of US management to negotiate with local unions, violations have yet to be reported formally to the HQ level of ChemCorp. In the views of both management and the GUF, this might be explained by the effectiveness of periodic fact-finding missions to subsidiary sites. Like MetalCorp, ChemCorp has established a working social dialogue to improve continuously the IFA, for example, through the recent agreement on a global safety committee (covering suppliers as well).

Given the overall poor employment standards in the industry, it seems somewhat surprising that no violations have been reported to ServiceCorp HQ. Since this firm has over 400,000 employees at more than 60 locations around the world, we would argue that this is more likely indicative of inadequate implementation and monitoring rather 
than of an efficient policy of prevention. Indeed, both management of ServiceCorp and UNI agree on the labour standards problems in the industry, and seem determined to cooperate in addressing them. Three years after the signing of the original agreement it has been successfully re-negotiated, with management agreeing to facilitate union organizing efforts as long as UNI and its affiliates promise to use the specified conflict resolution procedure and not to publicize problems. Moreover, management reserves the right to recognize unions that are not affiliated with UNI.

\section{Discussion and conclusion}

In this article, we have extended the model of practice transfer developed by Szulanski $(1996,2000)$ in order to investigate how employment-related practice transfer within TNCs and their global production networks is initiated under the condition of external actor involvement. Interpreted within an extended model of practice transfer, our findings contribute to a theory of IHRM that looks not only at structural or political aspects but, in line with Giddens' (1984) theory of structuration, at their recursive interplay for explaining practice transfer and diffusion in TNCs (see also Edwards et al., 1999). On the one hand, our findings extend previous analyses of IFAs as a policy instrument of organized labour by explicitly looking at the organizational and inter-organizational processes on the management side. On the other hand, we go beyond earlier studies in IHRM by making external actor involvement in the initiation phase of the transfer of practice explicit. Moreover, our findings push the boundary of traditional IHRM beyond the single enterprise by acknowledging the basic configuration of global production networks as a relevant background condition for the active dissemination of decent labour standards to the level of suppliers. As a welcome side-effect, our research brings labour and its collective representation 'back in' to the debate on the governance of networks. The issue of an active role for labour is rarely found in studies of inter-organizational networks from a management and organization perspective (see, for recent reviews, Borgatti and Foster, 2003; Provan et al., 2007). This also holds for research on global value chains in political science (Bair, 2008; Gereffi et al., 2005) and on global production networks by economic geographers (Coe et al., 2008; Nadvi, 2008).

In addition to that, we provide insights into the details of the process of initiating practice transfer. Using IFAs as an example, we can provide evidence on how external actor involvement can affect all stages of the initiation phase: initiatives to 'find the gap'; negotiation as an additional process step; and the mutual agreement on transfer. And we have pointed to union recognition and the extension of the scope of the IFA to suppliers as being the main issues of controversy. In so doing, we have brought additional sources of stickiness to light beyond those already identified in Szulanski's model, showing for example how labour's input and its organizational constellation affect negotiations and their outcomes, and impacts the scope of the agreement and its later implementation.

We have emphasized the role of labour as the initiator of the IFA process. Nevertheless, labour's organizational heterogeneity is indicative of the challenges it faces to find and articulate a common strategy, an issue of crucial importance beyond the policy field of IFAs (Hyman, 2005), but which cannot be addressed in this article. The existence of 
a stable coalition among GUF representatives, national unions, and works councils facilitates negotiations, and seems to have a positive impact on the type of monitoring embodied in an IFA. Moreover, our results are a strong indication that HQ level unions and employee representatives play a crucial role as gatekeepers and in advancing labour's interest in effective instruments for implementation and monitoring. In contrast, cases in which a stable coalition on labour's side between GUFs, national unions at HQ, and employee representative bodies was not forged, monitoring procedures remain informal and unstable.

According to our results, the viability of the conflict resolution mechanism strongly depends on its institutionalization and (inter-)organizational embeddedness. The greater the institutionalization of monitoring mechanisms and implementation measures, the more likely it is that an IFA will also cover suppliers and feedback complaints of violation into HQ level case handling. This is exemplified by the four cases that we presented in more detail. Nevertheless, this institutionalization at the top may be inadequate in global production networks that are more heterarchical and, at least at their periphery, based on market-like subcontracting. In contrast to that, network-like, long-term obligational relationships may well be more apt to facilitate the transfer of labour standards than market relationships (Fichter and Sydow, 2002; Frenkel and Kim, 2004). In regard to IFAs, it seems that the presence of additional (external) actors tests HQ management's capacity to reflect on the actual scope and form of its global production networks. In this respect, we found the inclusion of suppliers to be an issue for regulation in the greater majority of IFAs, but not in all of them. Even more importantly, the agreements embody three distinctly different approaches to dealing with conflicts arising over non-adherence to the IFA at a supplier: to ignore, to consider action (weak sanctions), or to act (strong sanctions).

The transfer of practices begins with the initiation phase, and we have shown how (global) unions as external actors impact this phase of the process. Clearly, the conditions of initiation are highly relevant for the subsequent phases of practice transfer. More detailed research is nevertheless needed to fully understand the complexity of the complete process and the relationship of the phases to each other, as well as the outcomes it produces. Case studies of the transfer process in and across TNCs at the local level could provide an in-depth and more thorough understanding of the dynamics of implementation, ramp-up and integration under the conditions of external actor involvement in TNCs and their global production networks. One prominent issue would be the actual role of suppliers and subsidiaries. Some first tier suppliers (Frenkel and Kim, 2004; Xue, 2008), but certainly not those at the periphery of global production networks (Stigzelius and Mark-Herbert, 2009), may need to be more than passive recipients of a top-down process of practice transfer for the goal of IFA implementation to be achieved. From first indications of disinterest and resistance from some local managers in our interviews, it seems necessary to find means for them to assume a more active part in the initiating (and implementing) of labour standards. The same is true with regard to the possibly active role of at least some subsidiaries of TNCs (most likely with a home base in continental Europe or Scandinavia, though arguably, HQ will keep the relational control over labour standards in those networks as well). Both phenomena also question the 
top-down-approach of IFAs as negotiated formal solutions at HQ. In this respect the notion of 'networking within hierarchy' (Edwards et al., 1999; our emphasis), coined to express the interplay between structural aspects and political agency in TNCs, can and should be complemented by the notion of 'networking across hierarchies' that evidently requires other modes of coordination than hierarchical fiat when unions (and eventually suppliers) as external actors are involved. A test for the opportunities of these influences, however, requires a methodology that captures the 'views from below' (Ferner et al., 2004: 370) - a step that is next on our research agenda.

\section{Notes}

1. The core labour standards refer to the prohibition of child labour (ILO co. 138 and 182) and forced labour (ILO co. 29 and 105), to non-discrimination and equal pay (ILO co. 100 and 111 ), and to freedom of association and collective bargaining (ILO co. 87 and 98).

2. These are: the International Metalworkers' Federation (IMF), the International Federation of Chemical, Energy, Mine and General Workers' Unions (ICEM), the Building and Wood Workers' International (BWI), and Union Network International (UNI).

3. On average, the corporations in our sample operate in 22 different international locations and employ a staff of ca. 95,000 people.

4. We found the diversity of the actor constellation and the strategic approach evident in these four cases confirmed by our other interviews as well. Significantly, in three quarters of the cases in our sample, national unions at the HQ level or a works council (or both) were cosignatories. This would confirm the relevance of these intermediary actors (see also Hammer, 2005; Tørres and Gunnes, 2003).

5. However, experts from other departments such as sourcing and CSR, as well as lawyers from the legal department, may also be involved.

6. While there are some scattered references in our interviews to local management - especially in the US - being a 'stumbling block' (ServiceCorp GUF rep) to the completion of IFA negotiations, nowhere did we encounter a systematic approach to involve local managers, despite their importance for the later implementation process. Also for unions, we have not encountered involvement of local unions from relevant countries, except in rare cases in which unions from Brazil and the US have been present in the world works council structure (MetalCorp) or are reported to indirectly participate in negotiations by being asked for feedback (ResourceCorp).

7. The recent move at ServiceCorp to hold two meetings a year might be interpreted as an opening toward more institutionalization as implementation progresses.

\section{Acknowledgements}

Former versions of this paper were presented at the 6th BAM Human Resource Management Special Interest Group Workshop, Cardiff Business School (30-31 March 2009), at the 15th World Congress of the International Industrial Relations Association (IIRA) in Sydney (24-27 August 2009), at the 23rd ANZAM Conference in Melbourne (2-4 December 2009) as well as at seminars at the Department of Management of the Monash University in Melbourne (9 December 2009), and the Australian School of Business of the University of New South Wales in Sydney (9 March 2010). We thank Stephen Frenkel at the latter institution for kindly hosting the third author during his sabbatical leave. Last but not least, we are grateful to Axel Haunschild, Kyoung-Hee Yu, and Hartmut Wächter, as well as the editors of this special issue and two anonymous reviewers for their insightful comments on an earlier version of this paper. 


\section{Funding}

We are especially indebted to the Hans-Böckler-Foundation for its generous financial support of the empirical research on which this paper is based (HBS Grant 2008-141-2), and to the German Research Foundation for its substantial grant (DFG Grant SY32/5-1) that allowed the third author to present and discuss the paper at the above-mentioned conferences and seminars.

\section{References}

Bair J (2008) Analysing economic organization: Embedded networks and global chains compared. Economy and Society 37: 339-364.

Bartley T (2007) Institutional emergence in an era of globalization: The rise of transnational private regulation of labor and environmental conditions. American Journal of Sociology 113(2): 297-351.

Borgatti SC and Foster PC (2003) The network paradigm in organization research: A review and typology. Journal of Management 29(6): 991-1013.

Bouquet $\mathrm{C}$ and Birkinshaw J (2008) Weight versus voice: How foreign subsidiaries gain attention from corporate headquarters. Academy of Management Journal 51: 577-601.

Brandl S (2006) Nachholende Internationalisierung? Zur Dynamik Internationaler Rahmenvereinbarungen. Industrielle Beziehungen - The German Journal of Industrial Relations 13(3): 270-281.

Brewster C, Wood G and Brookes M (2008) Similarity, isomorphism or duality? Recent survey evidence on the human resource management policies of multinational corporations. British Journal of Management 19: 320-342.

Coe NM, Dicken P and Hess M (2008) Global production networks: Realizing the potential. Journal of Economic Geography 8: 271-295.

Collings DG (2008) Multinational corporations and industrial relations research: A road less traveled. International Journal of Management Reviews 10(2): 173-193.

Croucher R and Cotton E (2009) Global Unions, Global Business. London: Middlesex University Press.

Cumbers A, Nativel C and Routledge P (2008) Labour agency and union positionalities in global production networks. Journal of Economic Geography 8(3): 369-387.

Dörrenbächer C and Geppert M (2006) Micro-politics and conflicts in multinational corporations: Current debates, re-framing, and contributions of this special issue. Journal of International Management 12: 251-265.

Edwards T and Rees C (2006) International Human Resource Management. Harlow: Pearson.

Edwards T, Colling T and Ferner A (2007) Conceptual approaches to the transfer of employment practices in multinational companies: An integrated approach. Human Resource Management Journal 17(3): 201-217.

Edwards T, Rees C and Coller X (1999) Structure, politics and the diffusion of employment in multinationals. European Journal of Industrial Relations 5(3): 286-306.

Ferner A and Almond P (eds) (2006) American Multinationals in Europe: Managing Employment Relations Across National Borders. Oxford: Oxford University Press.

Ferner A, Almond P, Colling T and Edwards T (2005) Policies on union representation in US multinationals in the UK: Between micro-politics and macro-institutions. British_Journal of Industrial Relations 43(4): 703-728.

Ferner A, Almond P, Clark I, Colling T, Ewards T, Holden L and Muller-Camen M (2004) The dynamics of central control and subsidiary autonomy in the management of human resources: Case-study evidence from US MNCs in the UK. Organization Studies 25(3): 363-391. 
Fichter M and Sydow J (2002) Using networks towards global labor standards? Organizing social responsibility in global production chains. Industrielle Beziehungen - The German Journal of Industrial Relations 9(4): 357-380.

Frenkel S (2001) Globalization, athletic footwear commodity chains and employment relations in China. Organization Studies 22(4): 531-562.

Frenkel S and Kim S (2004) Corporate codes of labour practice and employment relations in sports shoe contractor factories in South Korea. Asia Pacific Journal of Human Resources 21(1): 6-31.

Garcia-Pont C, Canales JI and Noboa F (2009) Subsidiary strategy: The embeddedness component. Journal of Management Studies 46(2): 182-214.

Gereffi G, Humphrey J and Sturgeon T (2005) The governance of global value chain. Review of International Political Economy 12(1): 78-104.

Geppert M and Williams K (2006) Global, national and local practices in multinational corporations: Towards a sociopolitical framework. International Journal of Human Resources Management 17(1): 49-69.

Geppert M, Matten D and Walgenbach P (2006) Transnational institution building and the multinational corporation: An emerging field of research. Human Relations 59(11): 1451-1465.

Giddens A (1984) The Constitution of Society. Cambridge: Polity Press.

Greer I and Hauptmeier M (2008) Political entrepreneurs and co-managers: Labour transnationalism at four multinational auto companies. British Journal of Industrial Relations 46(1): 76-97.

Hammer N (2005) International Framework Agreements: Global industrial relations between rights and bargaining. Transfer 11(4): 511-530.

Harzing A-W and Sorge A (2003) The relative impact of country of origin and universal contingencies on internationalization strategies and corporate control in multinational enterprises: Worldwide and European perspectives. Organization Studies 24(2): 187-214.

Hassel A (2008) The evolution of a global labor governance regime. Governance 21(2): 231-251. Hedlund G (1986) The hypermodern MNC - A heterarchy? Human Resource Management 25(1): 9-36.

Hellmann MF (2007) Social partnership at the global level: Building and Wood Workers' international experiences with International Framework Agreements. In: Schmidt V (ed.) Trade Union Responses to Globalization. A Review by the Global Union Research. Geneva: International Labour Office, 23-34.

Herrnstadt O (2007) Are International Framework Agreements a path to corporate social responsibility? Journal of Business and Employment Law 10(1): 187-224.

Hyman, R (2005) Shifting dynamics in international trade unionism: Agitation, organisation, bureaucracy, diplomacy. Labor History 46: 137-154.

ILO (1998) ILO Declaration on Fundamental Principles and Rights at Work. Geneva.

Jensen R and Szulanski G (2004) Stickiness and the adaptation of organizational practices in crossborder knowledge transfer. Journal of International Business Studies 35: 508-523.

Jick TD (1979) Mixing qualitative and quantitative methods: Triangulation in action. Administrative Science Quarterly 24: 602-611.

Kostova T, Roth K and Dacin MT (2008) Institutional theory in the study of multinational corporations: A critique and new directions. Academy of Management Review 33: 994-1006.

Lane C (2008) National capitalisms and global production networks: An analysis of their interaction in two global industries. Socio-Economic Review 6: 227-260.

Levy D (2008) Political contestation in global production networks. Academy of Management Review 33(4): 943-963.

Macneil I (1978) Contracts: Adjustments of long-term economic relations under classical, neoclassical and relational contract law. Northwestern University Law Review 72(1): 854-905. 
McSweeney B, Smith C and Fitzgerald R (2008) Remaking management: Neither global nor national. In: Smith C, McSweeney B and Fitzgerald R (eds) Remaking Management: Between Global and Local. Cambridge: Cambridge University Press, 1-16.

Müller T, Platzer H-W and Rüb S (2008) International Framework Agreements - opportunities and limitations of a new tool of global trade union policy. Briefing Papers No. 8/2008. Friedrich-Ebert-Stiftung, Division for International Development Cooperation, Global Trade Union Program. Bonn, Germany.

Nadvi K (2008) Global standards, global governance and the organization of global value chains. Journal of Economic Geography 8: 323-343.

Palpacuer F (2008) Bringing the social context back in: Governance and wealth distribution in global commodity chains. Economy and Society 37(3): 393-419.

Papadakis K (ed.) (2008) Cross-Border Social Dialogue and Agreements: An Emerging Global Industrial Relations Framework? Geneva: International Institute for Labour Studies.

Platzer H-W and Müller T (2009) Die globalen und europäischen Gewerkschaftsverbände Handbuch und Analysen zur transnationalen Gewerkschaftspolitik. Berlin: Edition Sigma.

Preuss L, Haunschild A and Matten D (2009) The rise of CSR: Implications for HRM and employee representation. International Journal of Human Resource Management 20(4): 953-973.

Provan KG, Fish A and Sydow J (2007) Interorganizational networks at the network level: A review of the empirical literature on whole networks. Journal of Management 33: 479-516.

Pudelko M and Harzing A-W (2007) Country-of-origin, localization, or dominance effect? An empirical investigation of HRM practices in foreign subsidiaries. Human Resource Management 46(4): 535-559.

Sako M (1992) Prices, Quality and Trust. Cambridge: Cambridge University Press.

Scherer AG and Smid M (2000) The downward spiral and the U.S. model business principles Why MNEs should take responsibility for the improvement of world-wide social and environmental conditions. Management International Review 40(4): 351-371.

Schömann I, Sobzack A, Voss E and Wilke P (2008) Codes of Conduct and International Framework Agreements: New Forms of Governance at Company Level. Dublin: European Foundation for the Improvement of Living and Working Conditions.

Stevis D (2010) International Framework Agreements and Global Social Dialogue: Parameters and Prospects. Employment Working Paper No. 47. Geneva: ILO.

Stigzelius I and Mark-Herbert C (2009) Tailoring corporate responsibility to suppliers: Manaing SA8000 in Indian garment manufacturing. Scandinavian Journal of Management 25: 46-56.

Subacchi P (2008) New power centres and new power brokers: Are they shaping a new economic order? International Affairs 84(3): 485-498.

Szulanski G (1996) Exploring internal stickiness: Impediments to the transfer of best practice within the firm. Strategic Management Journal 17(S2): 27-43.

Szulanski G (2000) The process of knowledge transfer: A diachronic analysis of stickiness. Organizational Behaviour and Human Decision Processes 82(1): 9-27.

Tempel A and Walgenbach P (2007) Global standardization of organizational forms and management practices? What new institutionalism and the business-systems approach can learn from each other. Journal of Management Studies 44(1): 1-24.

Tempel A, Edwards T, Ferner A, Muller-Camen M and Wächter H (2006) Subsidiary responses to institutional duality: Collective representation practices of US multinationals in Britain and Germany. Human Relations 59(11): 1543-1570.

Tørres L and Gunnes S (2003) Global Framework Agreements: A New Tool for International Labour. Oslo: Fafo.

Union Network International (UNI) (2001) Tätigkeitsbericht. 1. Weltkongress Berlin, 5-9 September 2001. Nyon: UNI. 
Waddock S (2008) Building a new institutional infrastructure for corporate responsibility. Academy of Management Perspectives 22(3): 87-108.

Wills J (2002) Bargaining for the space to organize in the global economy: A review of the AccorIUF trade union rights agreement. Review of International Political Economy 9(4): 675-700.

Xue H (2008) Local strategies of labor control: A case study of three electronics factories in China. International Labor and Working-Class History 73: 85-103.

Michael Fichter is a graduate of Stanford University (History). He received his doctorate in political science at the Free University of Berlin (FUB) in 1980. Until 1996 he was a researcher on trade union policies at the FUB Institute for Social Science Research. He is currently a senior lecturer in the Department of Political Science, FUB, and on the teaching staff of the Global Labour University. His research interests include trade union revitalization, Europeanization of labour relations, multinational corporations, and labour in globalization. He has published extensively on labour relations and trade unions in Germany and Europe. In 2002 he was a visiting fellow at the American Institute for Contemporary German Studies in Washington DC. From 2003-9 he was on the executive board, of the German Industrial Relations Association. Currently he is a member of the advisory board of the journal Industrielle Beziehungen and of the European Trade Union Institute in Brussels. [Email: mfichter@zedat.fu-berlin.de]

Markus Helfen holds a major degree in economics from the University of Trier and earned his doctorate in business administration in 2006 at Aachen University (RWTH Aachen). In 2001, he started his academic career as a Research Associate at Fraunhofer IAO (Stuttgart) in the field of service management. In 2003, he changed to RWTH Aachen as a Teaching Associate to complete his doctorate in industrial relations and international management. At present, he works as a Research Fellow at the Department of Management, Freie Universität Berlin. His research interests include organizational network theory, collective action, institutional analysis, and human resource management. [Email: markus.helfen@fu-berlin.de]

Jörg Sydow has earned his doctorate and habilitation in business administration at the Freie Universität Berlin where he is currently a Professor of Management at the School of Business \& Economics. Before this he held a chair for planning and organization at the University of Wuppertal, Germany, and was a Visiting Professor at Bentley College, universities in Innsbruck and Vienna, the University of Arizona, the University of New South Wales, and the University of Strathclyde. From 2004 until 2007 he was an International Visiting Fellow of the Advanced Institute of Management Research (AIM), London. He is a founding co-editor of two leading German journals, Managementforschung and Industrielle Beziehungen - The German Journal of Industrial Relations, and a member of the editorial boards of Organization Studies, Organization Science, Business Research, and Scandinavian Journal of Management. [Email: joerg.sydow@fu-berlin. de; Internet: http://www.wiwiss.fu-berlin.de/en/institute/management/sydow/index.html 